\title{
Landmark Discoveries in Calcium Metabolism Review of Literature
}

\author{
Sumit Sharma*, Prakshi Solanki, Haraprathap Yelishetty, Romil Lotta, Shubham Kr Bej and Suvarna Sharma \\ ${ }^{1}$ Department of ENT, Mayo Institute of Medical Sciences, India
}

Submission: September 23, 2019; Published: June 09, 2020

*Corresponding author: Sumit Sharma, Department of ENT, Mayo Institute of Medical Sciences, Faizabad Road, Gadia, Barabanki, 6 - Student Batch 2017-18, KMC - Manipal, India

\section{Introduction}

Calcium metabolism plays an integral role in maintaining homeostasis. Over $99 \%$ of the calcium present normally in the adult human body resides in the skeleton, where it provides mechanical stability and serves as a reservoir sometimes needed to maintain extracellular fluid (ECF) calcium concentration. Ionized calcium in the ECF must be maintained within a narrow range because of the critical role calcium plays in a wide array of cellular functions, especially in the neuromuscular activity, secretion, and signal transduction. Intracellular cytosolic free calcium levels are $\sim 100 \mathrm{nmol} / \mathrm{L}$ and are 10,000-fold lower than ionized calcium concentrations in the blood and ECF (1.1-1.3mmol/L). Cytosolic calcium does not play the structural role played by extracellular calcium; instead, it serves a signaling function. The steep chemical gradient of calcium from outside to inside the cell promotes rapid calcium influx through various membrane calcium channels that can be activated by hormones, metabolites, or neurotransmitters, swiftly changing cellular function. In blood, total calcium concentrations normally $2.2-2.6 \mathrm{mM}(8.5-10.5 \mathrm{mg} / \mathrm{dL})$, of which $\sim 50 \%$ is ionized [1].

Calcium metabolism derangements are linked with a wide variety of diseases the most commonly known of which are rickets, osteomalacia, osteoporosis, hyperparathyroidism, hypoparathyroidism, Paget's disease of bone, renal osteodystrophy, osteogenesis imperfect, osteitisfibrosacystica, osteopetrosis and fibrous dysplasia. This review of literature focuses on some of the innumerable discoveries which have helped the understanding of calcium metabolism and have benefitted patients over the years.

\section{Calcium}

Calcium was first isolated by Sir Humphry Davy in 1808. Davy isolated calcium by electrolysis, putting a mixture of calcium oxide with mercury (II) oxide on a platinum plate (anode) with a platinum wire partially submerged into mercury as the cathode.
Calcium was isolated from the calcium-mercury amalgam thus produced by distilling off the mercury [2].

But it was not until 1883 that the biological role of calcium was identified. Sir Sydney Ringer's four papers published in The Journal of Physiology in the early 1880s (1882a,b, 1883a,b) are rightly acknowledged as the starting point for the development of the modern understanding of the role of calcium in the contraction of the heart [3-8]. After this landmark discovery, many other physiological roles of calcium were identified by various researches like Ringer and Sainsbury who in 1894 described its role the development of the skeleton [4,9]. Campbell in 1988 demonstrated the role of calcium in conduction of nerve impulse to muscle [4,10], in 1988 Mooren \& Kinne [11] described the importance of calcium in cellular functions necessary for both normal and diseased states of the cell $[4,11]$, Heilbrunn and Wiercinski demonstrated that it was only calcium that could cause the muscle fiber to contract [4]. These and many other discoveries continued throughout the 19th and 20th century, but it was Dr. Fuller Albright who described the metabolism of calcium in detail in his book "Parathyroid Glands and Metabolic Bone Disease". He is credited with the discovery of calcium metabolism [12].

\section{Parathyroid Glands and Hormone}

The essential role parathyroid glands play to maintain life and its effect in pathophysiology is widely known today. This knowledge has the contribution of many inquisitive and great minds, few of which we are mentioning. It was Sir Richard Owen an English biologist, comparative anatomist and palaeontologist who first described the parathyroid glands - he found them in Indian rhinoceros in 1852 [13,14]. But the credit for the discovery of the parathyroid glands is generally accorded to Dr.Ivar Victor Sandstrom (1852-89), who, in 1880, when praelector in anatomy in the University of Uppsala, published the first systematic account 
of these then 'new glands' [15].

Although Adolph M. Hansen extracted parathyroid hormone in 1923 from his work on cattle, [16] the honour for the discovery of this hormone is given to Canadian James Bertram Collip who extracted it, named it parathyrin and used it to treat tetany in the year 1925 [17]. Parathormone was isolated and purified by Rasmussen and Craig in 1959 who also gave its polypeptide structure in the year 1962 [18,19].

The understanding of parathyroid gland functioning came gradually over the years. Greenwald identified its phosphaturic action in 1911 [20], followed by the discovery of its resorptive effect on the skeleton by Barnicot in 1948 [21]. The same year, Jahan and Pitts described its anti-calciuric action [22]. Its effect on small intestine was discovered much later by RV Talmage \& JR Elliott [23].

\section{Vitamin D}

Another important component of calcium metabolism is Vitamin D. It became the first vitamin to have a Nobel prize in its history when Adolf Windaus was given the Nobel prize for Chemistry in 1928 for his work on vitamins and sterols [24]. One of the first significant steps in the discovery of vitamin D was taken by Sir Edward Mellanby [25] who linked rickets with a fat soluble dietary nutrient. He wrote: "Rickets is a deficiency disease which develops in consequence of the absence of some accessory food factor or factors. It therefore seems probable that the cause of rickets is a diminished intake of an anti-rachitic factor, which is either [McCollum's] fat-soluble factor A, or has a similar distribution to it" [25]. Then in 1922, Elmer McCollum [26] and his colleagues identified an anti-rachitic factor that was not destroyed by oxidation and played an important role in bone formation. They named this factor Vitamin D [26].

Three teams of scientists - Hume \& Smith [27], Goldblatt \& Soames [28] and Steenbock \& Black [29], confirmed that sunlight (UV light) is a source of vitamin D in 1924 by their experiments on rats [27-29]. Hess \& Weinstock [30] simultaneously reported that UV irradiation of food not having anti-rachitic factor induced its production in these food items and could be used as a method to enrich food to improve public health [30].

Calciferol (Vitamin D-2) was purified and crystallized in the year 1931 by Reerink et al. [31] in London as well as by Windaus and his co-workers in the Netherlands [32]. The correct structure was described by Windaus and Thiele in 1936 [33, 34]. Then in 1936, Windaus et al synthesized cholecalciferol and named it Vitamin D3 [35]. While Velluz et al in 1955 gave the entire photochemical and thermal reactions involved in the production of cholecalciferol from ergosterol, [36] it was Holick et al. in 1980 who described the photoproduction of vitamin D in skin in its entirety [37] (Figure 1).

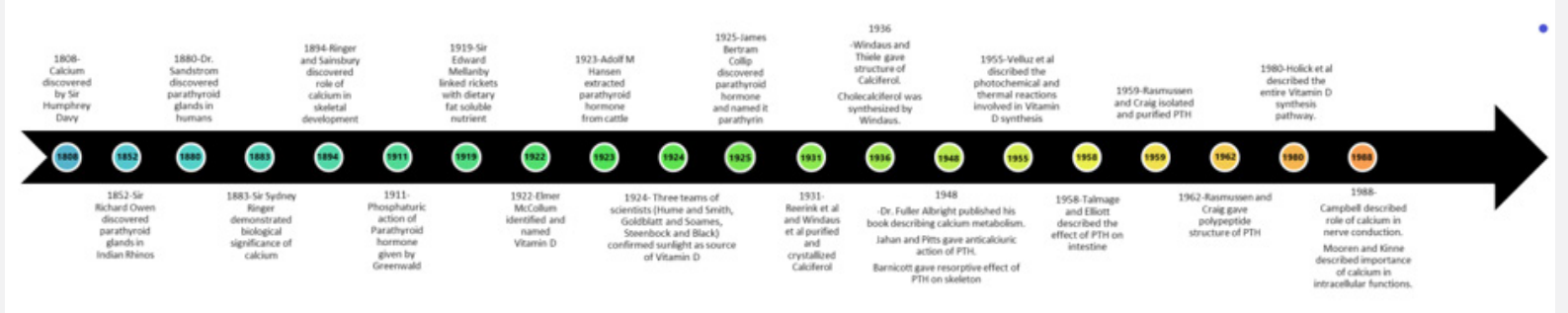

Figure 1: Photochemical and thermal reactions involved in the production of cholecalciferol from ergo sterol.

\section{Calcitonin}

Calcitonin was discovered in the year 1961 by Copp and purified in the same year by him and Cheney. Coppstated that, "While studying the control of its secretion in 1961, we discovered a second calcium-regulating hormone (calcitonin) which was released by hypercalcemia and lowered plasma calcium by inhibiting osteolysis. It is a straight-chain peptide with 32 amino acids and a 7-membered disulfide ring at the $\mathrm{N}$ terminal. It is produced by $\mathrm{C}$ cells which arise from the neural crest and is considered a neuropeptide hormone" [38].

\section{References}

1. Harrisons Principles of Internal Medicine, $19^{\text {th }}$ edition.
2. Davy H (1808) Electro-chemical researches on the decomposition of the earth; with observations on the metals obtained from the alkaline earth, and on the amalgam procured from ammonia. Philosophical Transactions of the Royal Society of London 98: 333-370.

3. Miller David J (2004) Sydney Ringer: physiological saline, calcium and the contraction of the heart. J Physiol 555(3): 585-587.

4. Jaiswal J K J Biosci (2001) Calcium -how and why? Journal of Biosciences 26(3): 357.

5. Ringer S (1882) Regarding the action of hydrate of soda, hydrate of ammonia, and hydrate of potash on the ventricle of the frog's heart. J Physiol 3: 195-202.

6. Ringer S (1882) concerning the influence exerted by each of the constituents of the blood on the contraction of the ventricle. J Physiol 3: 380-393. 


\section{Global Journal of Otolaryngology}

7. Ringer S (1883) A further contribution regarding the influence of the different constituents of the blood on the contraction of the heart. J Physiol 4: 29-42.

8. Ringer S (1883) A third contribution regarding the influence of the inorganic constituents of the blood on the ventricular contraction. J Physiol 4: 222-225.

9. Ringer S, Sainsbury H (1894) The action of potassium, sodium and calcium salts on Tubifexrivulorum. J Physiol 16: 1-9.

10. Campbell A K (1988) Methodol. Surveys Biochem Anal 19: 485-486.

11. Mooren F Ch, Kinne RKH (1998) Cellular calcium in health and disease. Biochim Biophys Acta 1406: 127-151.

12. Felsenfeld AJ, Levine BS, Kleeman CR (2011) Fuller Albright and our current understanding of calcium and phosphorus regulation and primary hyperparathyroidism. Nefrologia 31(3): 346-357.

13. Cave AJE (1953) Richard Owen and the discovery of the parathyroid glands. In: E. Ashworth (Ed.), Underwood. Science, Medicine and History. Essays on the Evolution of Scientific Thought and Medical Practice, Oxford University Press. US, pp. 217-222.

14. Kalra S, Baruah Manash P, Sahay Rakesh Sawhney Kanishka (2013) The history of parathyroid endocrinology. Indian J Endocrinol Metab 17(2): 320-322

15. J August (1938) On a New Gland in Man and Several Mammals (GlandulæParathyreoideæ). Journal of the American Medica Association 111(2): 197.

16. Medvei VC (1982) Lancaster: MTP Press Ltd. A history of endocrinology.

17. Collip JB (1925) The extraction of a parathyroid hormone which will prevent or control parathyroid tetany and which regulates the level of blood calcium. J Biol Chem 63: 395-438.

18. Rasmussen H, Craig LC (1959) Purification of parathormone by use of countercurrent distribution. J Am Chem Soc 81: 5003.

19. Rasmussen H, Craig LC (1962) The history of parathyroid polypeptides. Recent Prog Horm Res 18: 269-295.

20. Greenwald I (1911) The effect of parathyroidectomy upon metabolism. Am J Physiol 28: 103-132.

21. Barnicot NA (1948) The local action of the parathyroid and other tissues on bone in intracerebral grafts. J Anat 82: 233-248.

22. Jahan I, Pilts RF (1948) Effect of parathormone on renal tubular reabsorption of phosphate and calcium. Am J Physiol 155: 42-49.

23. Talmage RV, Elliott JR (1958) Removal of calcium from bone as influenced by the parathyroids. Endoicrinology 62: 217-222
24. The Nobel Prize.

25. Mellanby E (1919) An experimental investigation on rickets. Lancet 196: 407-412.

26. McCollum EV, Simmonds N, Becker JE, Shipley PG (1922) Studies on experimental rickets. XXI. An experimental demonstration of the existence of a vitamin which promotes calcium deposition. J Biol Chem 53: 293-312.

27. Hume EM, Smith HH (1924) The effect of irradiation of the environment with ultra-violet light upon the growth and calcification of rats, fed on a diet deficient in fat-soluble vitamins: the part played by irradiated sawdust. Biochem J 18: 1334-1345.

28. Goldblatt H. Soames KM (1923) Studies on the fat-soluble growthpromoting factor. Biochem J 17: 446-453.

29. Steenbock H, Black A (1924) Fat-soluble vitamins. XVII. The induction of growth-promoting and calcifying properties in a ration by exposure to ultra-violet light. J Biol Chem 61: 405-422.

30. Hess AF, Weinstock M (1924) Antirachitic properties imparted to lettuce and to growing wheat by ultraviolet irradiation. Proc Soc Exp Biol Med 22: 5.

31. Reerink EH, Van Wijk W (1931) The vitamin D problem. Biochem J 25 1001-1009.

32. Windaus A (1931) The chemistry of irradiated ergosterol. Proc R Soc (Lond) 108: 568-575.

33. Windaus A, Thiele W (1936) Überdie Konstitution des Vitamins D2. Ann Chem 521: 160-175.

34. Wolf George (2004) The Discovery of Vitamin D: The Contribution of Adolf Windaus. The Journal of Nutrition 134(1): 299-1302.

35. WindausA,SchenckF,WerderFV(1936)Überdasantirachitischwirksame Bestrahlungsproduktaus 7 Dehydrocholesterol. Z Physiol Chem 24: 100-103.

36. Velluz, L, Amiard G, Goffinet B (1955) Le précalciferol. Structure etphotochimie. Son role dans le genése di calciferol, et des photoisoméres de l'ergostérol. Bull Soc Chim 22: 1341-1348.

37. Holick MF, MacLaughlin JA, Clark MB, Holick SA, Potts JT, et al. (1980) Photosynthesis of previtamin D3 in human skin and the physiologic consequences. Science 210: 203-205.

38. Copp DH (1994) Calcitonin: discovery, development, and clinical application. Clin Invest Med 17(3): 268-277.

\section{Your next submission with Juniper Publishers will reach you the below assets}

- Quality Editorial service

- Swift Peer Review

- Reprints availability

- E-prints Service

- Manuscript Podcast for convenient understanding

- Global attainment for your research

- Manuscript accessibility in different formats

( Pdf, E-pub, Full Text, Audio)

- Unceasing customer service

Track the below URL for one-step submission https://juniperpublishers.com/online-submission.php 